the remains of pigmy elephants, and soon extended her interest to cave deposits in Crete, the Balearicswhere she discovered the unique 'antelope' Myotragus -Malta and Sardinia, working meticulously and earnestly and always alone. But her best work was done in Palestine where, at the invitation of Dr. Dorothy Garrod, she spent several seasons in the Mount Carmel and Bethlehem areas, her enthusiasm being in no way abated by the disturbed and often dangerous state of the country. Her paper on the faunas yielded by the Wadi el-Mughara caves (1937) was a classic example of palæo-ecological interpretation, and she continued this line of research in relation to other Palestinian faunas. Latterly she had turned her attention to African faunas, particularly of the Sudan, and shortly before her death completed a critical work on African buffaloes.

Though she always preferred to study specimens she had excavated herself, she was frequently con. sulted by archæologists from many countries concerning fragmentary animal remains; her long experience and careful methods of study enabled her to extract significant information from the most unpromising material, and her unique knowledge will be as greatly missed as will the charm of her generous and indomitable personality.

E. I. W.

WE regret to announce the following deaths:

Prof. G. H. Langley, during 1926-34 vice-chancellor of the University of Dacca, and honorary treasurer of the Aristotelian Society, on February 14, aged seventy.

Mr. A. W. Lay, until recently with Marconi's Wireless Telegraph Co., Ltd., who was known for his work in medical physics and electronic instrumentation, research, design and development, on February 3, aged fifty-eight.

Prof. J. Mattfeld, reader in the Botanical Gardens and Museums in Berlin-Dahlem, on January 19, aged fifty-six.

Dr. W. Bryant Mumford, British director of the Special Services Department of Public Information, United Nations Organization, formerly head of the Colonial Department at the University of London Institute of Education, on January 28.

\section{Bedford College for Women, London : Dr. Norah L. Penston}

Dr. Norah L. Penston, who has recently been appointed principal of Bedford College for Women, University of London, in succession to Miss G. E. M. Jebb, will take up her duties in September. Miss Penston graduated in the University of Oxford in 1927 with first-class honours in botany, and afterwards undertook research in plant physiology under Dr. W. O. James. The work, for which she was awarded her doctorate in 1929, involved a detailed study of the distribution of potassium in the potato plant. Dr. Penston was appointed demonstrator in the Botany Department of King's College, London, in 1929 and remained there until 1945, becoming in turn assistant lecturer and lecturer. She was also acting head of the Botany Department during the later years of the War. At King's College she continued her studies on the physiological importance of mineral elements in plants and published a number of papers, until her increasing administrative duties left little time for research. In 1945, following the amalgamation of Swanley Horticultural College with the South Eastern Agricultural College, Dr. Penston was appointed the first vice-principal of Wye College, University of London, and, since 1946, with the resignation of Mr. R. T. Pearl, has also been acting head of the Department of Biological Sciences of the College. An able player at tennis and badminton, Dr. Penston has more recently included archery among her activities. Her experience as teacher, research worker, administrator and warden of a students' hostel make her well fitted for her new appointment in Bedford College.

\section{Scientific Civil Service: Research Promotions}

IT is announced that further special posts have been created this year for individual research workers of exceptional merit under provisions included in the White Paper on the Scientific Civil Service (Cmd. $6679 ; 1945)$. The promotions this year again include two to the grade of deputy chief scientific officer,

\section{nd VIEWS}

which is regarded as broadly equivalent in status to an appointment to a university chair ; this is the second occasion on which special promotions on individual merit have been made under this scheme at this level.

Deputy Chief Scientific Officers .

Dr. J. S. Anderson, an inorganic chemist of high distinction, outstanding for his contributions in the field of solid systerns. His recent work has included a comprehensive study of the oxides of uranium, in the course of which the existence of a non-stoichiometric system was clearly demonstrated; work on thorium which showed that this element can form both divalent and trivalent compounds; and the development of a method for the study of diffusion in solution using radioactive tracers.

Dr. A. M. Uttley, who was trained in mathematics and psychology, his earlier researches being in the field of visual perception. In recent years he has been engaged on a variety of electronic researches at the Telecommunications Research Establishment, including R.A.F. training equipment, servo mechanisms, astro navigation and circuits. More recently he has suggested and applied fundamentally new concepts in the design of computing machines.

Senior Principal Scientific Officers :

Mr. R. D. H. Barklie, of the Royal Naval Scientific Service, has had wide experience as a research chemist in industry, in academic circles and in the Government service. He served in both World Wars, was an executive officer in the R.N.V.R. during 1940-45 and was mentioned in dispatches three times. $\mathrm{He}_{\mathrm{e}}$ has carried out valuable researches on chemical and physical problems of particular concern to the Royal Navy, and his work has been remarkable for its elegance and precision.

Dr. L. R. Cox, of the British Museum (Natural History), is the author of numerous palæontological papers dealing mainly with Mesozoic and Tertiary Molluses. His investigations of fossils from many parts of the world have thrown light on the geological age and relationships of the strata concerned, and his 